explored an old hernial sac but found it empty. The case was, moreover, seen with me by an eminent physician without the cause of the sudden attack being diagnosed.

The next opportunity I had was in March of this year when Dr. W. R. Speirs of Haltwhistle asked me to visit a female patient, aged 47 years, who suffered from jaundice, fever, and tenderness in the region of the gall-bladder. Attacks of biliary colic had lasted on and off for three years but generally yielded to hot applications and opium, and were not followed by jaundice, bile-stained urine, or chalky stools. When I first saw her on March 26th the abdomen was flat, but when I went to operate upon her gallbladder a week later the abdomen was swollen and a tumour of the size of an adult head existed in the middle line of the abdomen, the highest point of distension being rather below the umbilicus. It was clear that something had altered the appearance and in consequence the incision planned was changed to a cut in the middle line over the swelling. On reaching the peritoneum matted omentum and recent peritonitis were met with, and on passing the finger upwards towards the liver a gash of thick yellow bile escaped over the wound to the amount of some half a dozen ounces. On swabbing the discharge the upper surface of the liver was seen to be thickly covered with adherent lymph. The gall-bladder was next discovered in a mass of matted omentum, with a gangrenous-looking perforation on the anterior surface near the fundus. A gall-stone of small size was seen lying outside the gall-bladder. After the bile had been removed with swabs I enlarged the perforation with scissors and removed 13 small gallstones, packed the gall-bladder with gauze, and cleaned the abdomen. The perforation was invaginated and stitched with Lembert's sutures, one suture passing through the edge of the liver, owing to rottenness of the gall-bladder wall. The entire abdomen was now flushed out with salt solution and the wound was then closed absolutely. The patient suffered from shock and had a subnormal temperature for a few days and was fed rectally for some five days, but made a good recovery.

Those interested in district nursing may be pleased to learn that the entire preparation of the operation was carried out by one of those able and devoted women whose field in a country practice is so wide and whose hands are always fully occupied. The success of this operation has been largely due to Dr. Speirs, Dr. J. G. Stuart, and Dr. G. J. Williams of Haltwhistle.

With regard to the closure of the perforated gall-bladder I followed the lead of Mr. G. H. Makins, who recently read a paper at the Clinical Society of London on the invagination plan of closing perforations of the intestine met with in cases of strangulated hernia, and possibly he may be glad to know that his valuable paper ${ }^{\perp}$ has already borne fruit.

Carlisle.

\section{THE INFLUENCE OF DIET IN PREGNANCY ON THE WEIGHT OF THE OFFSPRING.}

BY D. NOEL PATON, M.D., F.R.C.P. EdIN.

SUPERINTENDENT OF THE RFSEARCH LABORATORY OF THE ROYAI COLLEGE OF PHYSICIANS OF EDINBURGH ; LECTURER ON PHYSIOLOGY IN THE EDINBURGH SCHOOL OF

$$
\text { MEDICINE. }
$$

(From the Laboratory of the Royal College of Physicians of Edinburgh.)

IN the course of a study of the diets of the families of the poorer labouring class in Edinburgh it became evident that poverty and the resulting deficiency in diet tell most severely in the early years of married life when a number of young children have to be provided for. As the children grow older their earnings increase the family income and remove the pinch of poverty. In this class every individual thus runs a risk of suffering from deficient nourishment at two periods-during the early years of childhood and during the first few years of married and, in women, of childbearing life. The further questions are thus raised: How far does malnutrition of the mother during pregnancy influence the growth of the child? Do the children of the

1 The LanceT, April 4th, 1903, p. 962. poor and badly nourished start life at a lower level than the offspring of those who are better fed?

Prochownick, ${ }^{1}$ whose object was to determine if by reducing the diet of the mother the size of the child might be so diminished that labour should be facilitated in cases of narrow pelvis, concludes that by restricting the diet of the mother the size of the child may be markedly diminished. He gives 48 cases in which, as a result of such regulation of the diet, the average weight of the child was : in 24 males 2960 grammes and in 24 females 2735 grammes. In eight cases in which the sex was unstated (excluding a case of twins) the weight was 3354 grammes. The average weight given in Vierordt's "Daten und Tabellen" for normal infants is: males, 3333 grammes; females, 3200 grammes ; average of both sexes, 3250 grammes. Thus in Prochownick's series the male children were 11 per cent. under the average and the females were 14 per cent.

It seemed to me that the investigation of the question in the human subject is by no means satisfactory, since so many disturbing factors are apt to come into play during preg. nancy and since it is really so difficult to determine whether the diminished size of the child is the result of less complete growth or simply the result of premature labour. In the lower animals the many physical and mental disturbances which may interfere with the course of pregnancy in the human subject are absent, while the course of gestation is rarely modified in length. In selecting an animal for the investigation it seemed advantageous to choose one which breeds freely and which has a short period of gestation. For this reason guinea-pigs were selected. Their period of gestation is ten weeks. As early as possible in their pregnancy the females were isolated, each being kept in a separate cage and weighed every three or four days.

The first point to be determined was whether well-fed guinea-pigs produced the same weight of young irrespectively of the number of the litter, and, if so, to ascertain what is the proportion of the weight of young produced to the weight of the mother. The following results were obtained from fully fed guinea-pigs :-

\begin{tabular}{|c|c|c|c|}
\hline I. -3 young born on June 3 rd weighed ... & ... & \multicolumn{2}{|c|}{210 grammes. } \\
\hline Mother weighed & $\ldots$ & 585 & \\
\hline II. -2 young born on Oct. 2 nd weighed ... & $\ldots$ & 200 & \\
\hline Mother weighed $\quad \ldots \quad \ldots \quad \ldots$ & $\ldots$ & 480 & ", \\
\hline II. -3 young born on Nov 5 th weighed ... & $\ldots$ & 285 & ", \\
\hline $\begin{array}{llll}\text { Mother weighed } & \ldots & \ldots & \ldots\end{array}$ & $\ldots$ & 600 &, \\
\hline IV. -2 young born on Nov. 16 th weighed & $\ldots$ & 215 & $"$ \\
\hline $\begin{array}{llll}\text { Mother weighed } & \ldots & \ldots & \ldots\end{array}$ & $\ldots$ & 545 & ," \\
\hline V. -2 young born on June 4th weighed... & $\ldots$ & 168 & \\
\hline Mother weighed $\quad \ldots \quad \ldots \quad \ldots$ & $\ldots$ & 505 & $"$ \\
\hline VI. -4 young born on Oct. 15 th weighed & $\ldots$ & 184 & $"$ \\
\hline Mother weighed $\quad \ldots \quad \ldots$ & & 555 & \\
\hline II. -3 young born on Nov. 10th weighed & $\ldots$ & 221 & ," \\
\hline Mother weighed & & & \\
\hline
\end{tabular}

In these seven observations, each gramme of mother produced the weight of young in grammes as shown in Table I.

TABLE I.

\begin{tabular}{|c|c|c|}
\hline $\begin{array}{l}\text { Number of observa- } \\
\text { tion. }\end{array}$ & Number of young. & $\begin{array}{l}\text { Weight of young per } \\
\text { gramme of mother. }\end{array}$ \\
\hline I. & 3 & 0.35 \\
\hline II. & 2 & $0 \cdot 40$ \\
\hline III. & 3 & 0.37 \\
\hline IV. & 2 & 0.39 \\
\hline $\mathrm{V}$ & 2 & 0.33 \\
\hline VI. & 4 & 0.33 \\
\hline VII. & 3 & 0.30 \\
\hline $\begin{array}{lll}\text { Average } & \ldots & \ldots\end{array}$ & $2 \cdot 7$ & 0.35 \\
\hline
\end{tabular}

These observations seem to show: (1) that the weight of young is independent of their number; and (2) that the weight of young produced in well-fed guinea-pigs bears a close relation to the weight of the mother.

In one case a well-fed guinea-pig produced an abnormally small weight of young. This was an old female which had only one young one weighing 155 grammes, while the mother weighed 700 grammes. Each gramme of mother had here produced only $0 \cdot 22$ gramme of young. 
While the-e observations were in progress another set of pregnant guinea pigs were kept upon a low diet which was regulated so as to check the rapir increase in weight of the pregnant animal. Misfortune attended this series. On two occasions the pregnant animal was destroyed by a dog and on another it received an injury which ended fatally. Of the seven animals kept upon low diet four yielded results as foliows :-

$$
\begin{aligned}
& \text { I. -2 young born on June 3rd weighed ... ... } 133 \text { grammes. } \\
& \begin{array}{lllllll}
\text { Mother weighed } & \ldots & \ldots & \ldots & \ldots & 595
\end{array} \\
& \text { II. -3 young born on Dec. 29th weighed... ... } 139 \quad \text {," } \\
& \begin{array}{lllllll}
\text { Mother weighed } & \ldots & \ldots & \ldots & \ldots & 507 \quad \text {, }
\end{array} \\
& \text { III.-Young (number not noted) born on Sept. } \\
& \begin{array}{lllllll}
18 \text { th weighed } & \ldots & \ldots & \ldots & \ldots & \ldots & 120
\end{array}
\end{aligned}
$$

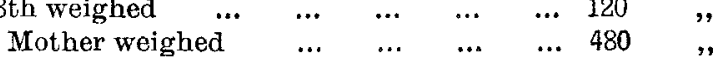

\begin{tabular}{|c|c|c|}
\hline $\begin{array}{l}\text { Number of observa- } \\
\text { tion. }\end{array}$ & Number of young. & $\begin{array}{l}\text { Weight of young per } \\
\text { gramme of mother. }\end{array}$ \\
\hline I. & 2 & 0.22 \\
\hline II. & 3 & $0 \cdot 27$ \\
\hline III. & - & 0.25 \\
\hline IV. & 2 & 0.23 \\
\hline $\begin{array}{llll}\text { Average } & \ldots & \ldots\end{array}$ & 25 & 0.248 \\
\hline
\end{tabular}

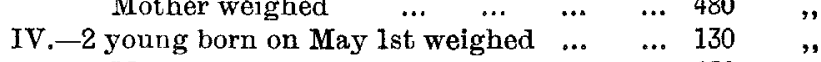

$$
\begin{aligned}
& \begin{array}{llllll}
\text { Mother weighed } & \ldots & \ldots & \ldots & \ldots & 639
\end{array}
\end{aligned}
$$

In these observations each gramme of mother produced the weight of young as shown in Table II. :-

TABLE II.

In none of these cases was the weight of young per gramme of mother equal to that in the well-fed guinea-pigs, the heaviest litter in an under-fed animal being 10 per cent. less per gramme of mother than the smallest litter in the well-fed animals. The average weight of the litter was no less than 28 per cent. below that of normal animals. In no case was there any indication that the births were premature, the young animals always presenting the character of full-time guinea-pigs and being active and vigorous.

The rate of increase of weight in the two series of guineapigs during the progress of gestation is shown in the accompanying chart.

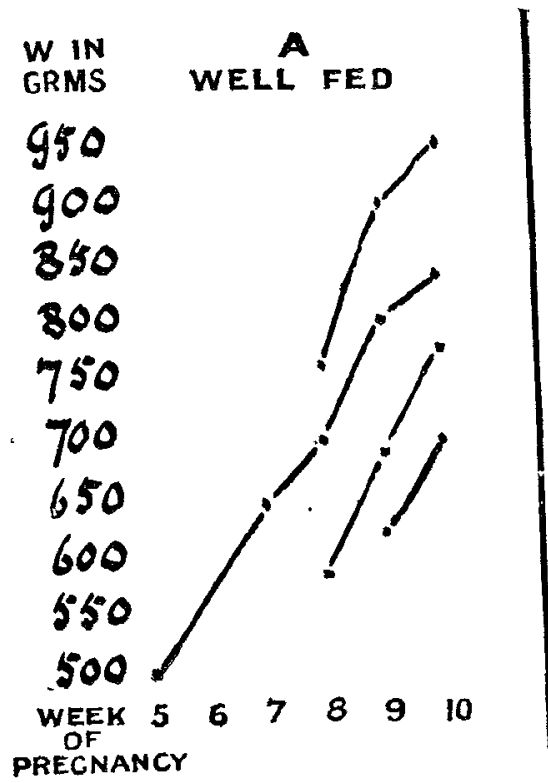

UNDER FED

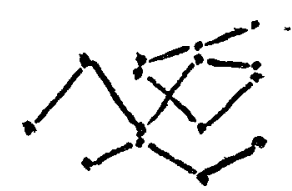

$\begin{array}{lllll}6 & 7 & 8 & 9 & 10\end{array}$

Showing rate of growth of four well fed (A) and of four under-

fed (B) guinea-pigs during the later months of pregnancy.

Conclusions.-These observations, though few in number, are so concordant that they warrant the conclusion that the size of the offspring depends very directly upon the diet and nutrition of the mother during pregnancy. While this explains the easy labours among the healthy lower classe and confirms Prochownick's conclusion that by dieting the mother the children of rickety women may be so reduced in size as to be viable, it also probably helps to explain the very high infant mortality among the very poor. The infant starts life at a low level and readily succumbs to the hardships to which it is too often subjected.
To the physiclogist the point of chief interest seems to by the demonstration of the limitations in the extent to which the tissues of the mother can be utilised for the construction of the embryo. The nourishment of the maternal tissues seems to take precedence over the nutrition of the foetus. Were this not the case, had the embryo the prior claim to nourishment, we should find that in badly nourished mothers each gramme would produce a greater proportionate weight of young than in well-nourished mothers. This is exactly the reverse of what occurs. The mother thus appears to pass on the surplus nourishment to the foetus and the better the nutrition of the maternal tissues the greater is the growth of the young in utero.

Edinburgh.

\section{THE BIOLOGICAL ACTION OF MOULDS ON ARSENICAL COMPOUNDS.}

BY H. DE R. MORGAN, M.A. OXON., M.R.C.S. ENG., L.R.C.P. LOND., D.P.H. CANTAB.

(From the Basteriological Department, Jenner Institute of Preventive Medicine.)

As far back as 1874 Selmi $^{1}$ discovered on the walls of rooms papered with arsenical papers (the inmates of such rooms suffering from arsenical poisoning) certain moulds giving off gas, which gas he considered to be arseniuretted hydrogen. Langendorf, when examining a case of arsenical poisoning from wall-papers at Breslau, came to the same conclusion, but it remained for Gosio in 1892 thoroughly to investigate the matter. He found that on keeping potato broth to which arsenic had been added in a cellar for a week a mould was formed on the broth which emitted an odour resembling garlic, which gas when passed through a solution of silver nitrate gave a precipitate which showed the presence of arsenic. The moulds be found to be almost exclusively penicillium glaucum, aspergillus glaucus and mucor mucedo, and by experimenting with different varieties of moulds he discovered that penicillium brevicaule evolved this toxic gas in the highest degree. He concluded therefore that the toxic effects from arsenical wall-papers were due to moulds growing on such papers in damp rooms and emitting an arsenical gas. Gosio also proved by experiment that penicillium brevicaule was sensitive to very minute traces of arsenic, for on being grown in the presence of even 0.000001 gramme of arsenious acid the garlic-like odour was emitted. He found also that in the presence of large quantities of arsenic the growth of the mould was not inhibited. These two experiments I have tested myself and I found that on growing penicillium brevicaule on bread paste in a small flask, to which had been added one gramme of sodium arsenite, a very intense odour of garlic was emitted. The arsenical gas produced by growing penicillium brevicaule in the presence of arsenic was proved by Biginelli to be diethylarsine. He obtained his proof by the following method. ${ }^{2}$ The gas produced by growing penicillium brevicaule in the presence of sodium arsenite when passed into a hydrochloric acid solution of mercuric chloride causes the formation of colourless crystals of the double compound As- $\mathrm{H}\left(\mathrm{C}_{2} \mathrm{H}_{5}\right)$ $+2 \mathrm{Hg} \mathrm{Cl}_{2}$ - hence he recognised it as diethylarsine.

As regards the cultural reactions of pencillium brevicaule it grows readily on all ordinary media, both liquid and solid, showing a decided preference, however, for starches and sugars, such as bread paste, potato, saccharose broth, and glycerine agar. Its optimum temperature is about $37^{\circ} \mathrm{O}$.; it grows much less rapidly at $20^{\circ} \mathrm{C}$. It coagulates litmus milk at $37^{\circ} \mathrm{C}$. on the fifth day without acidifying it and grows freely on all sugar media without production of gas or acidity.

In confirming the experiments of Gosio and others I made use of Francis Cevey's suggestion of taking an Erlenmeyer flask containing bread crumbs, the flask and contents having been previously plugged and sterilised in the steamer on three successive days, adding either the suspected substance or a known quantity of an arsenical compound, and inoculating the mixture with penicillium brevicaule by pouring over

1 Selmi: Nuovo processo generale per la ricerca delle sostanze venefiche e osservazioni sullo sviluppo d'idrcgene delle muffe (Bologna, 1875).

\footnotetext{
2 Atti Reale Accademia dei Lincei, 1900.
} 